Schmerzlose Schwellung unter dem Kinn

\title{
Was wächst da im Mundboden?
}

In der Praxis stellte sich ein 20-jähriger Mann vor, der berichtete, dass sich unter dem Kinn seit zwei bis drei Monaten eine nicht schmerzhafte Schwellung gebildet habe. Er gab keine Schluckstörung oder Atemnot an. Es bestand kein fieberhafter Infekt. Die HNO-Spiegelbefunde waren unauffällig. In der Sonografie des Mundbodens imponierte eine echoreiche ovale Struktur. Das MRT des Mundbodens zeigte die nebenstehenden Bilder.

Welche Verdachtsdiagnose stellen Sie? Wie sollte weiter vorgegangen werden?
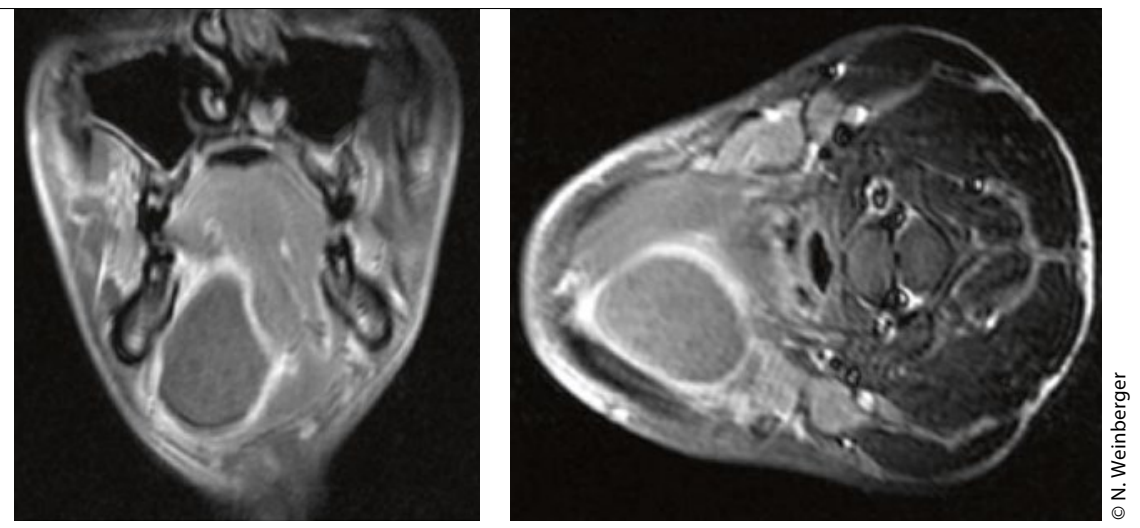

\section{Hier steht eine Anzeige.}

照 Springer 